\title{
Cervical Lymphoepithelioma-Like Carcinoma
}

National Cancer Institute

\section{Source}

National Cancer Institute. Cervical Lymphoepithelioma-Like Carcinoma. NCI Thesaurus.

Code C40193.

A variant of cervical squamous cell carcinoma characterized by the presence of islands of cells with uniform, vesicular nuclei and prominent nucleoli and a dense lymphocytic infiltrate. 